\title{
Structural and Spectroscopic (Ft-Ir, Ft-Raman, Nmr, Uv- Vis) Investigations on 4-Methoxyacetophenone Using Quantum Computational Methods
}

\author{
Srinivasan. $\mathrm{M}^{1}$, Jayasheela. $\mathrm{K}^{2}$, Prabhu. $\mathrm{T}^{3}$, Periandy. $\mathrm{S}^{4}$ \\ ${ }^{1,3}$, A.V.C. College [Autonomous], Mayiladuthurai, Tamil Nadu-609 305. \\ ${ }^{1}$ KSK College of Engineering \& Technolgy,Kumbakonam, Tamil Nadu-612 702 \\ ${ }^{2,4}$, Kanchi mamunivar Cener for post graduate Studies, Lawspet, Pondicherry-605 008. \\ Email: sheelaraj051990@gmail.com
}

\begin{abstract}
In the present study, Gaussian computations are carried out using B3LYP method with 6-311++G (d,p) basis sets and the corresponding results are compared with the experimental values. FT-IR, FT-Raman, NMR and UV spectra of 4-Methoxyacetophenone (4MAP) are recorded, the fundamental vibrational frequencies are tabulated and assigned. The change in the chemical environment of the compound is studied. The ${ }^{13} \mathrm{C} \mathrm{NMR}$ and ${ }^{1} \mathrm{H}$ NMR chemical shifts are calculated using the gauge-independent atomic orbital (GIAO) method, with the B3LYP functional and the $6-311++\mathrm{G}(\mathrm{d}, \mathrm{p})$ basis set and their spectra is compared with the experimental spectra. A study on the electronic and optical properties; absorption wavelengths, excitation energy, dipole moment and frontier molecular orbital energies are also performed using HOMO - LUMO methods. The calculated HOMO and LUMO are displayed with energy gap, which show the occurrence of charge transformation within the molecule. NLO properties related to polarizability, hyper-polarizability are discussed and also performed thermodynamical properties. The Docking of the molecule with different virus/ bacteria is carried out in order to understand the biological activity of the molecule.
\end{abstract}

Index Terms- DFT, FT-IR, FT-Raman, Docking Thermodynamical analysis, NMR, UV-Vis analysis.

\section{INTRODUCTION}

Acetophenone is one of the most typical aromatic carbonyl, which shows interesting photochemical properties [1,2]. It is of additional interest that aminoacetophenone derivatives possess some degree of local anesthetic activities [3]. Acetophenone is one of the most aromatic carbonyl compound it shows interesting photochemical properties. It acts as an anticancer agents, an intermediate for pharmaceutical industry, and also a accelerator of photopolymer. 4'-Methoxyacetophenone is found in alcoholic beverages [4]. Acetophenone is a colorless liquid with a sweet pungent taste and odor resembling the odor of oranges. A mild irritant to skin and eyes. Vapors can be narcotic in high concentrations. Used as a flavoring, solvent, and polymerization catalyst. Acetophenone is a methyl ketone that is acetone in which one of the hydrogens of the methyl group has been replaced by a phenyl group. It has a role as a photosensitizing agent, an animal metabolite and a xenobiotic. This colourless, viscous liquid is a precursor to useful resins and fragrances. Acetophenone has been identified in many types of plants and as a volatile component of honey. Acetophenone is used as an intermediate for pharmaceutical, plastic and resin production [5]. It is primarily used as a riot-control agent (tear gas) and in Chemical Mace [6,7] 4'Methoxyacetophenone is a trace constituent of oil of Piper longum (long pepper). 4'-Methoxyacetophenone is present in cranberry (Vacciniumoxycoccus) and other fruits, tomato, anise
(Pimpinellaanisum), grilled and roasted beef and sherry [8]. 4'-Methoxyacetophenone is a solid, pale

yellow flavoring agent with a hawthorn like odor. It is soluble in most fixed oils and propylene glycol, and it is insoluble in glycerin and mineral oil. It is obtained by chemical synthesis. This flavoring substance or its adjuvant may be safely used in food in the minimum quantity required to produce its intended flavor. It can be used alone or in combination with other flavoring substances or adjuvant. It is also termed pmethoxyacetophenone. [9]. 4'-Methoxyacetophenone absorbed on silica-alumina catalyst [10].4'Methoxyacetophenone is a flavouring ingredient and adjuvant; useful in vanilla, nut, tobacco and butter flavor. Actophenone and its derivatives, having additionally substituted saturated alkyls, oxygenated alkyl groups, thio groups, additional aromatic groups, unsaturated aliphatic side chains, and other functional groups, are serving as flavor \& fragrance ingredient in soaps, detergents, cosmetics, and perfumes as well as in foods, beverages, and tobacco.4'-Methoxyacetophenone is used as a component of perfumes and as chemical intermediate in the manufacture of pharmaceuticals, resins, flavouring agents. Hence, many works have been reported time to time on Acetophenone and its derivatives [1-7], however the quantum computational analysis supported by spectral studies has not been reported on 4-Methoxyacetophenone so far, hence the present work is undertaken to analyse the NBO, NLO, HOMO - LUMO, NMR, UV and Vibrational characteristics of the molecule using DFT methods and spectral techniques. 


\section{METHODS}

\subsection{Experimental details}

The compound under investigation 4Methoxyacetophenone was purchased in the powder form from Sigma-Aldrich chemicals company, USA. The FT-IR spectrum of the compound was recorded using a Bruker IFS $66 \mathrm{~V}$ spectrometer in the range of $4000-400 \mathrm{~cm}^{-1}$. The spectral resolution is $\pm 2 \mathrm{~cm}^{-1}$. The sample was prepared using KBr pellet technique. The FT-Raman spectrum of 4Methoxyacetophenone was recorded at in the region 4000$130 \mathrm{~cm}^{-1}$ of wavelength using Nd-YAG laser at $1064 \mathrm{~nm}$. The NMR spectra were recorded in $\left(\mathrm{CdCl}_{3}\right)$ chloroform solvent phase in the range of $0-200 \mathrm{ppm}$ for ${ }^{13} \mathrm{C}$ with the scanning interval of $20 \mathrm{ppm}$ and ${ }^{1} \mathrm{H}$ in the range $0-12 \mathrm{ppm}$ with the scanning interval of $1 \mathrm{ppm}$. The UV-Visible spectrum was recorded in the range of 200-1100 nm, with the scanning interval of $100 \mathrm{~nm}$, using UV-1700 series instrument.

\subsection{Quantum chemical calculations}

All the quantum chemical computations in the present work are performed using the Gaussian 09 software programs with Gaussview [11,12] on a Pentium IV/3.02GHz personal computer and the wave numbers and geometrical parameters were computed using B3LYP (Becke's three parameter Lee-Yang Parr highbred methods) functional with $6-311++\mathrm{G}(\mathrm{d}, \mathrm{p})$ basis set. Density functional theory (DFT) has been proved to be extremely useful in treating electronic structure of molecules. The vibrational frequency and structural parameter of 4-Methoxyacetophenone was done using the same B3LYP functional and 6-311++G (d, p) basis sets for optimized geometry and the purity of the modes are confirmed by the total energy distribution (TED) method, computed using VEDA-4 program[13].

The geometry corresponding to the minimum energy has been obtained using the potential energy surface (PES) scan technique. The electronic transitions were identified using the NBO (Natural bonding orbitals) analysis, HOMO-LUMO (Gaussum3.0) [14] prediction of excitation energies and oscillator strength using time-dependent TDSCF-B3LYP method. Same thing is also verified using UV-Vis experimental spectrum. The NMR chemical shift was carried out by gauge independent atomic orbitals (GIAO) method in combination with B3LYP and 6$311++\mathrm{G}(\mathrm{d}, \mathrm{p})$ methods. In addition, Mullikan charges, dipole moment and thermodynamical properties of the title molecule are also computed using the same functional and basis set.

\section{RESULT AND DISCUSSION \\ 3.1. Conformational analysis}

The optimized molecular structure of the present molecule was used for conformational analysis, which was performed by potential energy surface scan techniques using a semi empirical method PM6, which is proven to be much efficient and quicker [15] than B3LYP, by varying the dihedral angle in the steps of $10^{\circ}$ over one complete rotation. The graphical result, total energy (Hartree) verses scan coordinates of the conformer, is presented in Fig 1. The graph clearly shows that there are four conformers at minimum energy levels one at $61^{\circ}$ the second at the $180^{\circ}$ and the third and fourth at $301^{\circ}, 420^{\circ}$ respectively. All the minimum energy level has the same value of energy 0.09557 Hartree. These conformers are structurally identical, serve as the most stable conformer of the compound. The maximum energy is observed for the conformer at $121^{\circ}, 241^{\circ}$ and $361^{\circ}$ with energy value 0.09378 Hartree, this is the least stable or most unstable conformer of the compound. One of the most stable conformer is used for all the computational analysis in the present work.

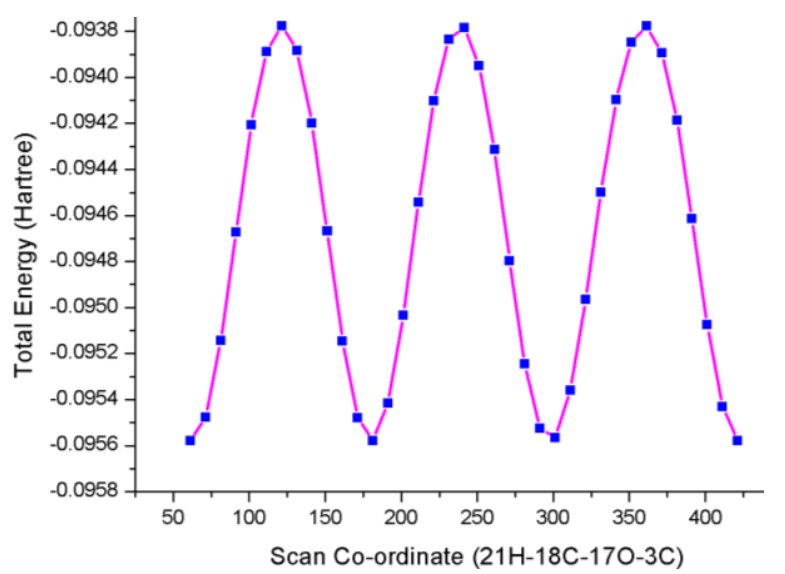

Fig. 1. The potential energy curve of 4Methoxyacetophenone

\subsection{Molecular geometrical analysis}

The optimized molecular structure of the title molecule 4-Methoxyacetophenone along with the numbering of atoms is presented in Fig.2. The optimized structural parameters bond length, bond angle, dihedral angle of the compound calculated by B3LYP functional and $6-311++\mathrm{G}(\mathrm{d}, \mathrm{p})$ basis sets is presented in Table 1 . In the case of $\mathrm{C}-\mathrm{C}$ single bonds, the bond lengths are expected at $1.45 \AA$ and $\mathrm{C}=\mathrm{C}$ around $1.35 \AA$ [16]. In the title molecule, among $\mathrm{CC}$ bonds within the benzene ring, C2-C3, C3-C4, C1-C6 get the value as $1.39 \AA, 1.404 \AA$ and $1.407 \AA$ respectively. This value is slightly less than the expected value for single bond and slightly higher than that of double bond, this show there is a kind of electronic redistribution around the ring, known as Conjugation, which makes the bond length almost equal them. The other $\mathrm{CC}$ bond lengths $\mathrm{C} 1-\mathrm{C} 2, \mathrm{C} 4-\mathrm{C} 5$ and $\mathrm{C} 5-$ C6 are $1.38,1.393$ and $1.397 \AA$, which show there is unevenness in the distribution of electrons among the bonds within the ring. This unevenness may be due to the methoxy groups attached to the phenyl ring, the highly electronegative $\mathrm{O}$ atoms may influence the electronic arrangement within the ring.

The value of O17- C18 bond length value is $1.42 \AA$, which is in agreement with reference value $1.43 \AA$ [17], but the bond length value of C3-O17 is $1.357 \AA$. This shows that the electronic distribution around the carbon atom within the benzene ring is completely different from that methyl group. The C11-O13 bond length value is 
International Journal of Research in Advent Technology, Vol.7, No.4, April 2019

E-ISSN: 2321-9637

Available online at www.ijrat.orgS

$1.21 \AA$, which is clearly a double bond, as it in agrees with reference value $1.20 \AA$ [18] for double bond.

The comparison of the $\mathrm{C}-\mathrm{H}$ bond lengths in the molecule gives an interesting result; all the $\mathrm{C}-\mathrm{H}$ bonds in the benzene ring have values closer to $1.08 \AA$. This shows the aromaticity (conjugation) in the benzene ring has considerably reduced the $\mathrm{C}-\mathrm{H}$ bond lengths due to delocalization of the electrons.

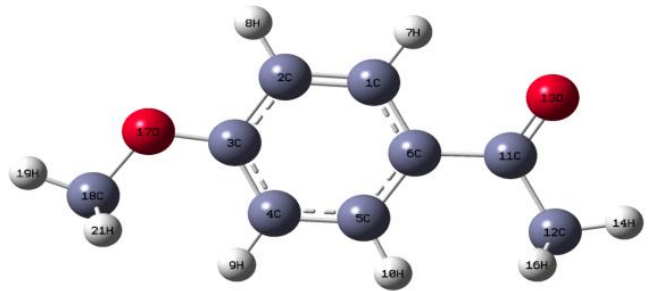

Fig.2 Structure of 4-Methoxyacetophenone

\subsection{Mullikan and Natural charge analysis}

The atomic charge on the atoms of the molecule has an important influence on the dipole moment, molecular polarization, electronic structure, molecular reactivity and vibrational frequency of different bonds. It is also pertinent to NMR chemical shift and NLO property of molecular system. The charges on the atom of the molecule 4-Methoxyacteophenone was computed by both Mullikan population analysis (MPA) method and Natural atomic charge (NAC) method using B3LYP functional with $6-311++\mathrm{G}(\mathrm{d}, \mathrm{p})$ basis set [20], which is presented graphically in Fig. 3 and the values are tabulated Table. 2. All the carbon atoms in the benzene ring are expected to be equally negative as there used to electronic conjugation within the ring. But, the MPA predicts that $\mathrm{C} 1, \mathrm{C} 4$ and $\mathrm{C} 6$ are positive and C6 \& $\mathrm{C} 1$ are highly positive, with values $1.362655 \& 0.583199$ respectively. C4 has the least positive value 0.022901. The carbon atom C6 have maximum positive charge in Mullikan atomic charge due to the attachment of phenone group and it is predicted to be negative in Natural Atomic charge. The carbon atom C4 (0.022\&-0.296) shows that it is nearer to neutral in Mullikan Atomic Charge but it is negative in Natural charge. The Carbon atom C3 $(-0.418 \& 0.348)$ is negative Mullikan charge and positive in Natural charge. This variation occurs due to the presence of methoxy group at C4. The carbons atoms C2 $(-0.609 \&-0.238)$ is found to be negative in both methods and C5 (-1.214 \& 0.148) shows maximum negative charge in Mullikan Atomic Charge.

From the methoxy group, the carbon atom C18 ($0.309 \&-0.206)$ atom is found to be negative in both methods. The O17 $(-0.151 \&-0.533)$ is also negative in both the cases. In phenone group, the carbon atom C11 (0.275 ) is found to be negative in Mullikan Atomic charge and maximum positive $\mathrm{C} 11$ (0.554) in Natural charge due to the attachment of electrophilic influence of $\mathrm{C}=\mathrm{O}$. Remaining carbon C12 (-0.465\&-0.667) atom in this group shows negative in both the cases.

All the hydrogen atoms are found to be positive in both MPA and NAC methods. But there is considerable variation in their magnitudes around 0.15 , the variation is naturally due to the presence of $\mathrm{O}$ atoms in the functional groups.

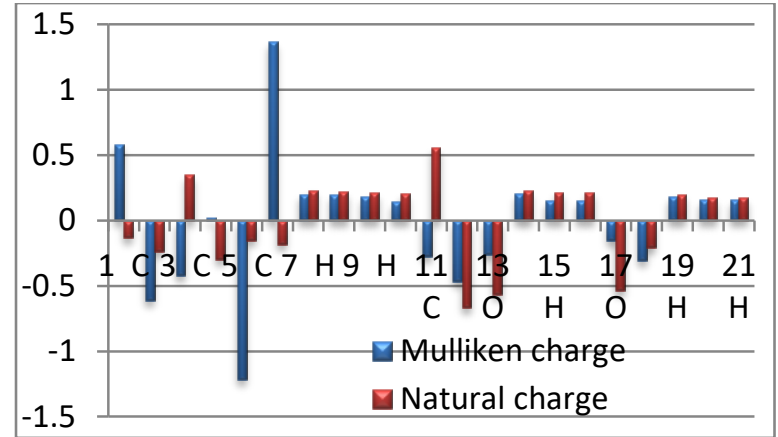

Fig. 3. The graphical plot of MAC and NAC in 4Methoxyacetophenone

\subsection{NMR Assessment}

The ${ }^{1} \mathrm{H}$ and ${ }^{13} \mathrm{C}$ chemical shift calculations of the compound was made by gauge independent atomic orbital (GIAO) theory in combination with B3LYP method using $6-311+\mathrm{G}(\mathrm{d}, \mathrm{p})$ basic set in gas and $\mathrm{CDCL}_{3}$ phases. The calculated ${ }^{13} \mathrm{C}$ and ${ }^{1} \mathrm{H}$ NMR chemical shifts (ppm) of 4 Methoxyacetophenone are shown in Fig.4 \& 5 respectively. The shifts are calculated for gas and $\mathrm{CDCL}_{3}$ solvent phases and the experimental values are presented in the Table.3. The aromatic carbon atoms are generally having the shifts in the range of $120-130$ ppm [21]. The chemical shift value of $\mathrm{C} 3, \mathrm{C} 11$ are found experimentally at $160,196 \mathrm{ppm}$ respectively. This value is very high when compared to other carbon atoms in the aromatic ring which may be due to the attachment of $\mathrm{O}$ atoms with these carbon atoms. The $\mathrm{C} 12$ and $\mathrm{C} 18$ chemical shift values are 26 and 55 ppm respectively; these are adjacent $\mathrm{C}$ atoms, so the charges would have been pulled from them, besides they are also in aliphatic group. Hence the shift is found to be lower than the expected value. Remaining C1, C2, C4, C5 and $\mathrm{C} 6$ chemical shift values are within the literature range.

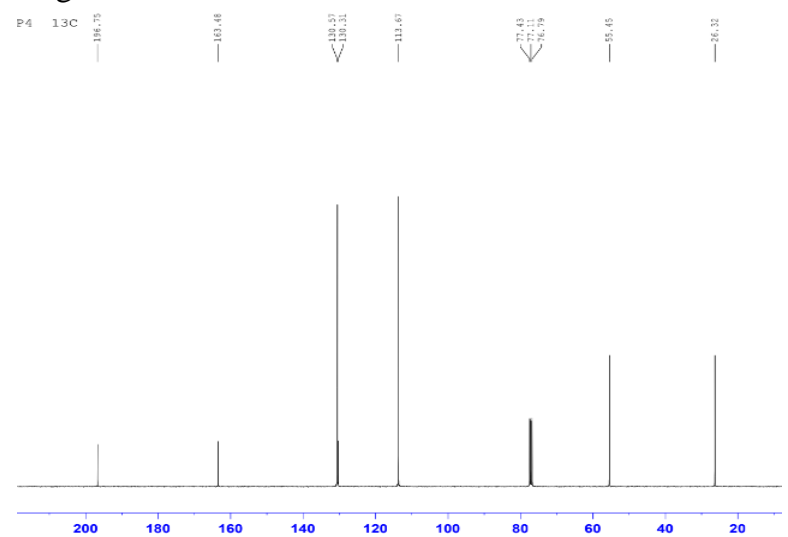

Fig. 4. ${ }^{13} \mathrm{C}$ NMR Experimental spectrum for 4Methoxyacetophenone 


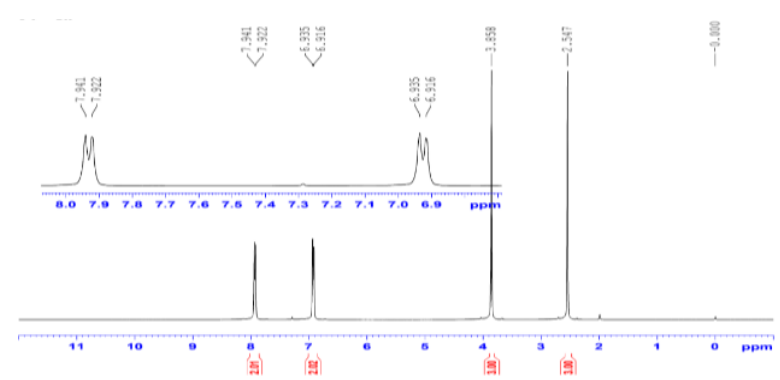

Fig. 5. ${ }^{1}$ H NMR Experimental spectrum for 4Methoxyacetophenone

\subsection{Vibrational Analysis}

The title molecule contains 21 atoms and hence 57 normal modes of vibrations. All these fundamental modes are identified in recorded FT-IR and FT-Raman spectra along with their intensity, the corresponding theoretical values are also stimulated. The experimental and stimulated spectra are given in Fig. $6 \& 7$ respectively. The theoretical frequencies were scaled using suitable scaling factors, comparing with the experimental frequencies. The experimental and theoretical frequencies, both scaled and un-scaled, along with the assignments are presented inTable.4.

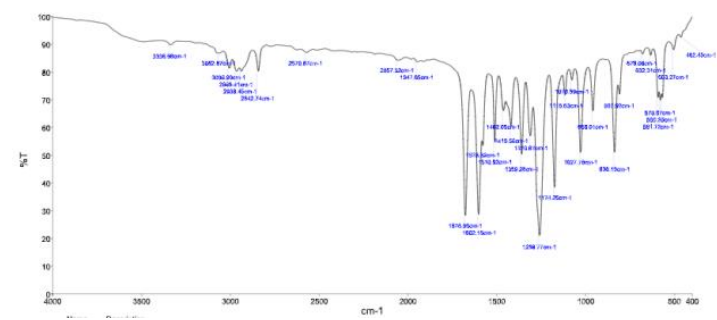

Fig. 6. Experimental Infrared spectra of 4Methoxyacetophenone

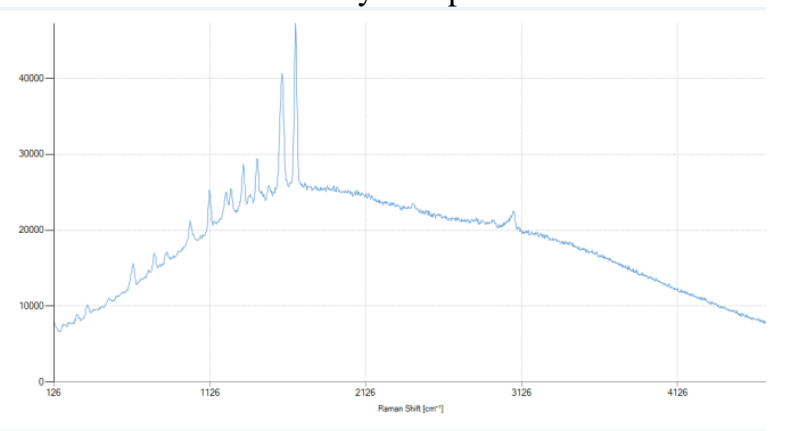

Fig. 7. Experimental Raman spectra of 4Methoxyacetophenone

\section{C-H vibrations}

The $\mathrm{C}-\mathrm{H}$ stretching vibrations in phenyl ring are normally observed in the region $3100-3000 \mathrm{~cm}^{-1}$ and less than 3000 $\mathrm{cm}^{-1}$ for non-aromatic compounds [23]. In the present molecule, $\mathrm{C}-\mathrm{H}$ bands observed in between the values 3103 $-2911 \mathrm{~cm}^{-1}$. FT-IR values are found at $3115,3061,3036$, 2980, 2972, 2930 and $2910 \mathrm{~cm}^{-1}$ and at 3084, 3061, 3003 $\mathrm{cm}^{-1}$ in FT-Raman. There are only Four $\mathrm{CH}$ bonds in phenyl ring, but six bands have more than $3000 \mathrm{~cm}^{-1}$ wave number, which indicates even the $\mathrm{CH}$ bonds in aliphatic substitutional groups have acquired the value of aromatic $\mathrm{CH}$, this may naturally be due to the presence of $\mathrm{O}$ atoms in aliphatic group.
The $\mathrm{C}-\mathrm{H}$ plane bending vibrations for both ring and methyl group are expected in the region $1286-1127 \mathrm{~cm}^{-1}$ and very useful for characterization purposes [24]. In this study, these bands are observed at $1284-1128 \mathrm{~cm}^{-1}$ in scaled value. The FT-IR values are found at 1315, 1278, 1278, 1197 and $1064 \mathrm{~cm}^{-1} \& 1276,1150,1100,1080$ and 1022 $\mathrm{cm}^{-1}$ in FT-Raman are agreed with expected value.

\section{$C=C$ and $C-C$ vibrations}

These $\mathrm{C}=\mathrm{C} \& \mathrm{C}-\mathrm{C}$ stretching modes are usually assigned in aromatic compounds between $1600-1500 \mathrm{~cm}^{-1}$ for $\mathrm{C}=\mathrm{C}$ and $1500-1400 \mathrm{~cm}^{-1}$ for $\mathrm{C}-\mathrm{C}$ respectively $[25,26]$. In the present case, the CC double bonds are observed at $1664 \&$ $1550 \mathrm{~cm}^{-1}$ in FT-Raman and FT-IR respectively. The first band value is higher than the expected range, which may be due to the attachment of ketonic group. Those corresponding scaled theoretical values are 1588 and 1551 $\mathrm{cm}^{-1}$.

The C-C single bond is observed at $1483 \mathrm{~cm}^{-1}$ in FT-IR and $1463,1439,1428,1425,1420 \mathrm{~cm}^{-1}$ in FT-Raman. All these above values are in very much within the expected range. The corresponding theoretical values are 1487, $1453,1443,1430,1426$ and $1422 \mathrm{~cm}^{-1}$ respectively. This observation is much significant in the spectrum of present molecule as the values are highly characteristic of the aromatic ring itself. All the modes are confirmed by their PED values. The PED values are also supporting the intensities of vibrations. The bands assigned to CCC in plane bending and out of plane bending vibrations are observed between 990-710 \& 339-250 $\mathrm{cm}^{-1}$ respectively. The CCC out of plane bending vibrations has appeared in combination with $\mathrm{CH}$ out of plane bending vibrations.

\section{$\boldsymbol{C}=\mathrm{O}$ and $\mathrm{C}-\mathrm{O}$ Vibrations}

The $\mathrm{C}=\mathrm{O}$ stretching mode is expected in the region 1740 $1660 \mathrm{~cm}^{-1}$ [27]. In this present work, the $\mathrm{C}=\mathrm{O}$ asymmetric stretching is assigned at $1751 \mathrm{~cm}^{-1}$ in FT-IR. The deformation mode of $\mathrm{C}=\mathrm{O}$ is expected in the regions, $625 \pm 70$ and $540 \pm 80$ [28]. In this molecule the deformation mode of $\mathrm{C}=\mathrm{O}$ is present at 686 and $684 \mathrm{~cm}^{-1}$ in FT-IR and Raman respectively. These deformation modes are found mixed with $\mathrm{CC}$ bending modes.

The C-O bond stretching modes of vibrations are usually observed in the region 1150-1000 $\mathrm{cm}^{-1}$ [29]. In this molecule, the C-O stretching vibrations are found at 1197 $\mathrm{cm}^{-1}$ in FT-IR and $1158 \mathrm{~cm}^{-1}$ in FT-Raman, whose theoretical values are found at 1161 and $1155 \mathrm{~cm}^{-1}$ respectively. The band was found within the allowed region. The bending vibration found at 578 and $488 \mathrm{~cm}^{-1}$ in FT-IR and FT-Raman. Its observed scale factor value is 567 and 489 respectively. There is small shift in frequencies towards higher side which may be due to the influence of phenyl ring from where the these bonds may derive charges due to the presence of oxygen atom.

\subsection{NBO Analysis}

The Natural bonding orbital (NBO) analyses is an important method of studying the various possible donors and acceptors in the molecule, with their occupancy, hybridization values and the stabilization energy for each transition in each position. The inter and intra molecular interaction can also be studied using NBO analysis [30]. This overall stabilization energy $\mathrm{E}(2)$ for all the donor - 
acceptor transitions from the second-order perturbation theory is reported in table. 5. The NBO occupied orbital is Lewis-type (bond or lone pair) and unoccupied orbital is non-Lewis type (anti-bond or Rydgberg). NBO analysis was performed on the 4-methoxyacetophenone molecule at the B3LYP/6-311+G(d,p) level. The fock matrix was elucidating in the donor-acceptor interactions in the NBO analysis [31].

$$
E(2)=\Delta E_{i j}=q_{i} \frac{F(i, j)^{2}}{E_{i}-E_{j}}
$$

Where $q_{i}$ is the donor orbital occupancy, $\varepsilon_{\mathrm{i}}$ and $\varepsilon_{\mathrm{j}}$ are Fock matrix diagonal elements and $F(i, j)$ is the off diagonal element [32].

The high stabilization energy of the transitions gives a measure of the probabilities of the transitions; which indicate the highly probable transitions in this molecule are C3-C4 to C1-C2 $\left(\pi-\pi^{*}, 34.9 \mathrm{Kcal} / \mathrm{mol}\right), \mathrm{O} 17$ to $\mathrm{C} 3-\mathrm{C} 4$ (n$\left.\pi^{*}, 31.8 \mathrm{Kcal} / \mathrm{mol}\right), \mathrm{C} 3-\mathrm{C} 4$ to $\mathrm{C} 5-\mathrm{C} 6\left(\pi-\pi^{*}, 23.8\right.$ $\mathrm{Kcal} / \mathrm{mol}), \mathrm{C} 1-\mathrm{C} 2$ to $\mathrm{C} 3-\mathrm{C} 4\left(\pi-\pi^{*}, 23.4 \mathrm{Kcal} / \mathrm{mol}\right), \mathrm{C} 5-\mathrm{C} 6$ to $\mathrm{C} 1-\mathrm{C} 2\left(\pi-\pi^{*}, 20.5 \mathrm{Kcal} / \mathrm{mol}\right), \mathrm{O} 13$ to $\mathrm{C} 11-\mathrm{C} 12\left(\mathrm{n}-\sigma^{*}\right.$, $19.9 \mathrm{Kcal} / \mathrm{mol}), \mathrm{C} 5-\mathrm{C} 6$ to $\mathrm{C} 11-\mathrm{O} 13\left(\pi-\pi^{*}, 19.5 \mathrm{Kcal} / \mathrm{mol}\right)$, O13 to C6-C11 (n- $\left.\sigma^{*}, 18.44 \mathrm{Kcal} / \mathrm{mol}\right), \mathrm{C} 5-\mathrm{C} 6$ to $\mathrm{C} 3-\mathrm{C} 4(\pi$ $\left.-\pi^{*}, 16.4 \mathrm{Kcal} / \mathrm{mol}\right), \mathrm{C} 1-\mathrm{C} 2$ to $\mathrm{C} 5-\mathrm{C} 6\left(\pi-\pi^{*}, 16.23\right.$ $\mathrm{Kcal} / \mathrm{mol})$ and $\mathrm{O} 17$ to $\mathrm{C} 3-\mathrm{C} 4\left(\mathrm{n}-\sigma^{*}, 13.92 \mathrm{Kcal} / \mathrm{mol}\right)$. The list indicates that all the $\pi-\pi^{*}$ transitions are taking place within the benzene ring, while the first $\mathrm{n}-\pi^{*}$ transition takes place in aceto group and the second $n-\pi^{*}$ which seems relatively less probable in methoxy group. $n-\sigma^{*}$ also takes place in aceto group. But, the experimental UVVis spectrum shows only three peaks; two in $\pi-\pi^{*}$ region and one in $n-\pi^{*}$ region, which means all other transitions are not favored by the selection rules. The HOMO-LUMO analysis can predict exactly which transitions appear in experimental and theoretical spectra, as discussed below.

\section{7. $U V$-Visible study}

The UV-Visible of 4-Methoxyacetophenone are computed at B3LYP/6-311++G (d,p) level along with TD-SCF functional. The computations are performed for both gas and solvent (Ethanol) phases. The calculated and experimental excitation energies, oscillator strength (f) and absorption wavelength $(\lambda)$ and HOMO-LUMO contributions are presented in the Table 6.

In this case of electronic transitions, the energy gap in gas phase are found to be $3.834,4.688,4.797,4.317,4.395$, $4.544,4.755,4.772,4.936$ and $5.052 \mathrm{eV}$, their respective absorption wavelength are 323.3,264.4, 258.4, 231.6, 227.4, 220.0, 210.2, 209.5, 202.5 and $197.9 \mathrm{~nm}$. The respective oscillator strength, which theoretically predict the intensity of the bands are $0.0001,0.3692,0.0019$, $0.000,0.0059,0.1338,0.004,0.0203,0.000,0.0024$ respectively, which indicate only the second transition will appear in the spectrum as its oscillator strength is considerably large. In solvent (Ethanol) phase where the experimental spectrum is recorded, the respective energy gaps are 3.986, 4.514, 4.747, 4.444, 4.538, 4.610, 4.941, 5.042, 5.088, 5.166 eV, the wavelengths are 311.0, 274.6, 261.1, 225.1, 220.3, 216.8, 202.3, 198.2, 196.5, 193.5.nm respectively. The oscillator strengths for these values $0.0001,0.4672,0.0019,0.1616,0.000,0.0058,0.0063$, $0.0003,0.0777,0.3173$ respectively. According to these oscillator strength values, the three peaks in the experimental spectrum are 205, 216, and $271 \mathrm{~nm}$ respectively. Though the first two $\pi-\pi^{*}$ transitions are not expected theoretically, they have been recorded experimentally. Based on the NBO analysis, the first two peaks in the experimental spectrum are due to the electronic transitions; $\mathrm{C} 1-\mathrm{C} 2$ to $\mathrm{C} 3-\mathrm{C} 4 \quad\left(\pi-\pi^{*}\right.$, $23.4 \mathrm{Kcal} / \mathrm{mol})$, and $\mathrm{O} 13$ to $\mathrm{C} 11-\mathrm{C} 12$ (n- $\sigma^{*}, 19.9$ $\mathrm{Kcal} / \mathrm{mol}$ ) respectively. The strong peak at $271 \mathrm{~nm}$ is due to the $\mathrm{O} 17$ to $\mathrm{C} 3-\mathrm{C} 4\left(\mathrm{n}-\pi^{*}, 31.8 \mathrm{Kcal} / \mathrm{mol}\right)$, whose HOMO - LUMO contribution is the highest, 97\%. It is the reason why only this peak appears in the theoretical spectrum.
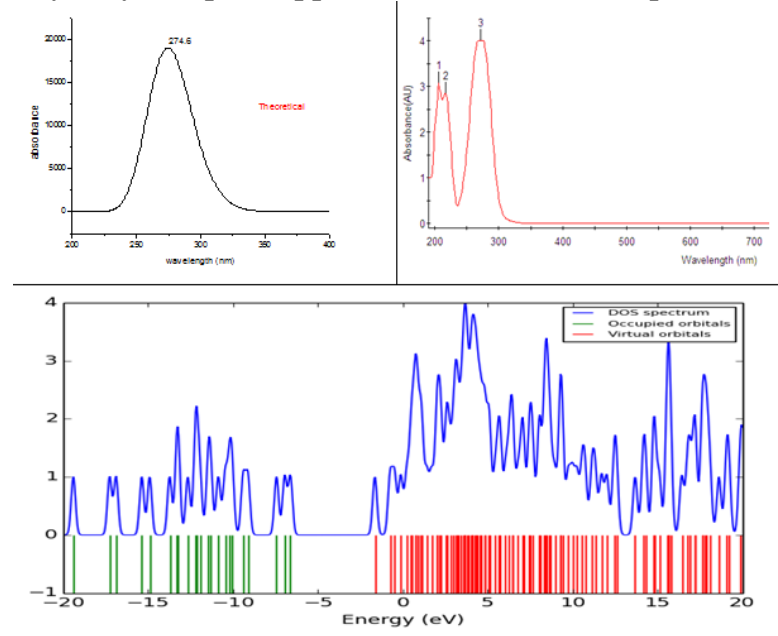

Fig. 8. Experimental and Theoretical and UV-Vis Spectra of using 4-Methoxyacetophenone

\subsection{HOMO-LUMO Analysis}
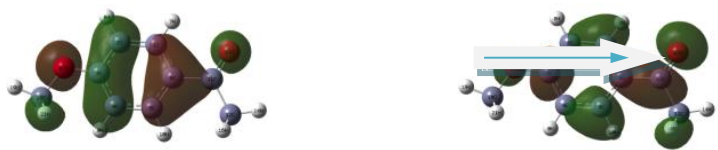

Fig. 9. Frontier molecular orbitals of 4Methoxyacetophenone

Electrophilicity index is a measure of the energy lowering due to the maximum electron flow between the donor (HOMO) and the acceptor (LUMO). The Table 7 shows that the electrophilicity index of the title molecule using B3LYP method was --0.13462 eV. The dipole moment in a molecule is another electronic property which determines the strength of the interaction. When a molecule has a large dipole moment inter molecular interaction are very strong. The calculated dipole moment value of the component is 4.9769 Debye in gas phase. The chemical hardness is a good indicator of the chemical stability. The chemical hardness of the title molecule found to be around $-0.00895 \mathrm{eV}$. The chemical softness was around -11.1769 $\mathrm{eV}$.

\subsection{MEP (molecular electrostatic potential) Analysis}

The MEP is used to analysis the reactive sites of molecules in three dimensions by DFT computation. A MEP surface is an electron density mapping in terms of electrostatic potential energy. The MEP surface also determines the molecular size, shapes, charge densities and reactive sites. 
International Journal of Research in Advent Technology, Vol.7, No.4, April 2019

E-ISSN: 2321-9637

Available online at www.ijrat.orgS

Different values of electrostatic potential at the surfaces are represented by different colours [33]. Red represents region of most negative electrostatic potential, blue represents region of most positive electrostatic potential and green represents region close to zero electrostatic potential. In most MEP diagrams Fig. 10., electrophilic site is indicated as red and nucleophilic site is represented in blue.

The electrostatic potential increase in the order red<orange<yellow< green<blue [34]. The colour code of the maps found to vary in the range of -5.636 e- 2 (deepest red) to 5.636 e-2 (deepest blue). In this present molecule $\mathrm{C} 11=\mathrm{O} 13$ is red and yellow regions of the MEP surfaces are related to electrophonic reactivity. The methoxy group $\left(\mathrm{O}-\mathrm{CH}_{3}\right)$ lies in the blue region. The benzene ring of the present molecule lies in the region of greenish blue it clearly shows that potential is close to zero. The atoms $\mathrm{C} 12, \mathrm{H} 14, \mathrm{H} 16$ are also in the greenish blue region.

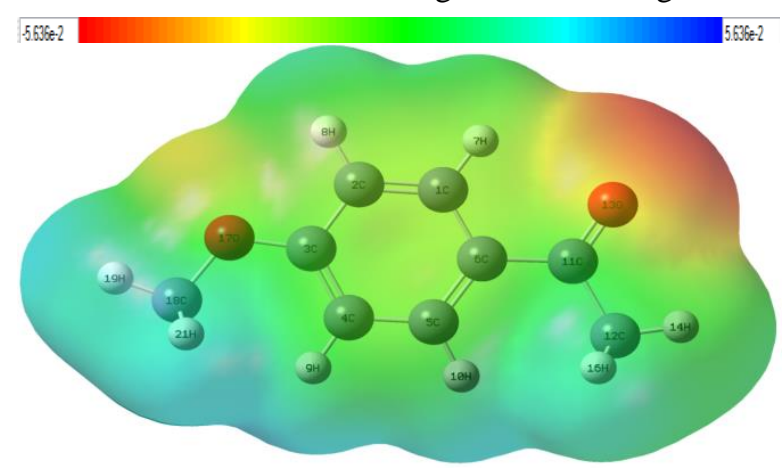

Fig. 10 MEP of 4-Methoxyacetophenone

\subsection{Thermodynamic properties}

From vibrational analysis of the present molecule, the thermodynamic functions such as standard heat capacities $\left(C_{m}^{0}\right)$, standard entropies $\left(S_{m}^{0}\right)$ and standard enthalpy changes $\left(H_{m}^{0}\right)$ were obtained from theoretical harmonic frequencies at B3LYP/6-311++G (d,p) level, and the values are presented in Table 8 . Based on table, as the temperature increases from $100 \mathrm{~K}$ to $300 \mathrm{~K}$, the thermodynamic functions also increase linearly at one atmospheric pressure. This increase may be due to the fact that vibrational intensities are increasing with increase temperature, along with the increase in rotational and translational energy in accordance with equipartition theorem [35,36]. The correlation graphs are shown in Fig.11.

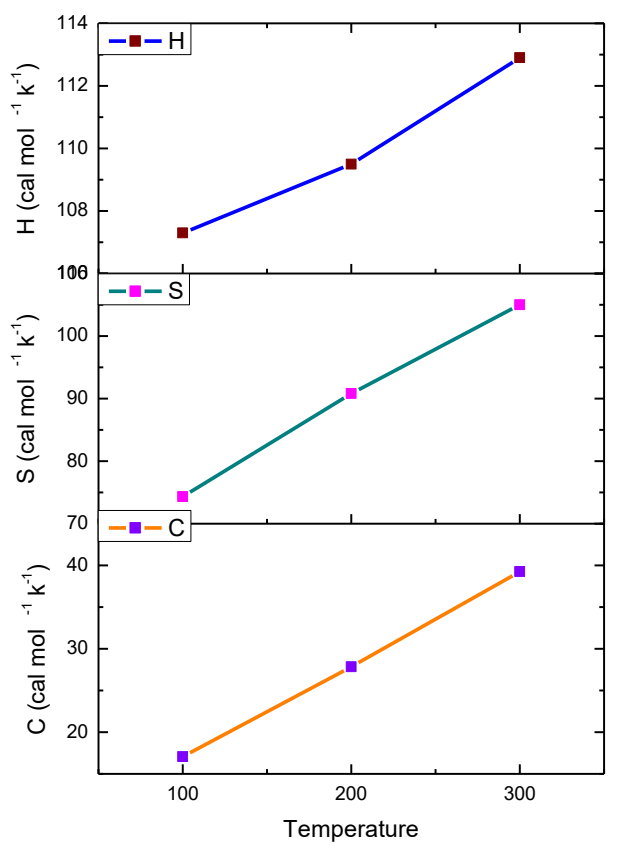

Fig. 11. Thermodynamic analysis of 4-methoxy Acetophenone

\subsection{Docking Analysis}

Molecular docking is an innovative technique for predicting and clearly understanding the molecular mechanisms of the molecule under study as ligands. This technique determines the probable ligand- protein interactions and the binding affinity values of the molecules at the binding sites. To investigate the binding affinity of the present molecule with many target proteins, the Auto Dock program 4.0 [37] was used. The structure of protein-ligand binding is determined using Activity Spectra (PASS) [38] and other online tools for various activities. The optimized geometry of the present molecule is used as ligand.

In present studies, the docking with high resolution is found with $(5 \mathrm{VCX})$ as receptor. The analysis shows that the docking take place at two sites CYS 190 and ASP 251, using Hydrogen bonds at $\mathrm{C}_{11}=\mathrm{O}_{13}$ (phenone group) and $\mathrm{O}_{17}$ (Methoxy group) of title ligand molecule, with bond length of 2.0, $2.3 \AA$ respectively. This details of the ligand-protein interaction is shown in Table.9.and the graphical representation is shown in Fig.12. The present docking study indicates the possibility that the title molecule may be used as anti cancer agent. 


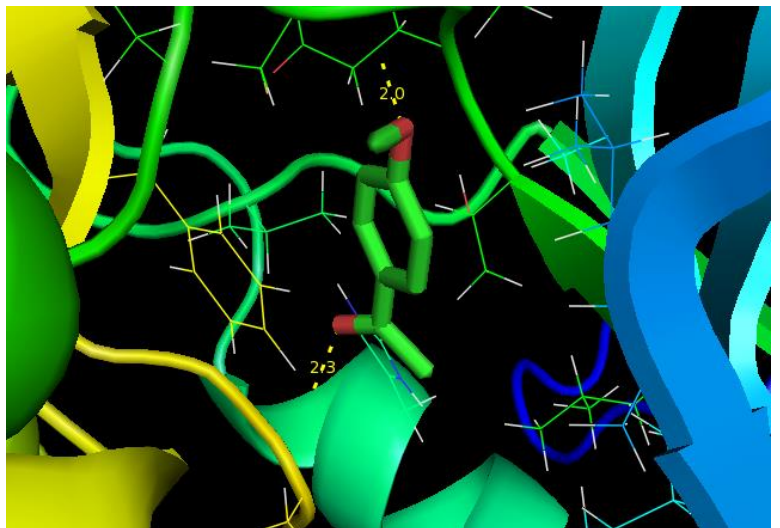

Fig. 12. Docking analysis of 4-Methoxyacetophenone

\section{CONCLUSION}

The molecule 4-Methoxyacetophenone is subjected to conformational analysis for finding the most stable configuration. The structural analysis of the compound indicates that there is considerable change in the structural parameters due to the presence of $\mathrm{O}$ atoms in both aceto and methoxy groups, these structural changes have caused respective vibrational changes which are identified and discussed. There is also a considerable variation in the atomic charges, which lead to variation in NMR chemical shift values. The NBO analysis predicted all the most probable sites in the molecule for electronic transitions, which are confirmed by the experimental UV-Vis spectrum recorded. The main transitions are found to be the due to the same substitional groups, methoxy and ketone groups. The docking study reveals that this molecule can be used as anti- cancer.

\section{TABLES:}

Table. 1.

Optimized Geometrical parameter for 4Methoxyacetophenone Computed at B3LPY/6-311++G(d,p).

\begin{tabular}{|c|c|c|c|c|c|}
\hline \multicolumn{2}{|c|}{$\begin{array}{c}\text { Bond } \\
\text { Length (̊) }\end{array}$} & $\begin{array}{c}\text { XR } \\
\text { D }\end{array}$ & \multicolumn{2}{c|}{$\begin{array}{c}\text { Bond Angle } \\
\left({ }^{\circ}\right)\end{array}$} & XRD \\
\hline C1- & 1.3 & 1.3 & C2-C1- & 12 & 121 \\
C2 & 8 & 7 & C6 & 1 & \\
\hline C1- & 1.4 & 1.4 & C2-C1- & 12 & 120. \\
C6 & 0 & 1 & H7 & 0 & 5 \\
\hline C1- & 1.0 & 1.0 & C6-C1- & 11 & 119. \\
H7 & 8 & 8 & H7 & 8 & 0 \\
\hline C2- & 1.4 & 1.4 & C1-C2- & 12 & 119. \\
C3 & 0 & 1 & C3 & 0 & 3 \\
\hline C2- & 1.0 & 1.0 & C1-C2- & 12 & 121. \\
H8 & 3 & 9 & H8 & 1 & 9 \\
\hline C3- & 1.3 & 1.3 & C3-C2- & 11 & 118. \\
C4 & 9 & 9 & H8 & 8 & 8 \\
\hline C3- & 1.3 & 1.3 & C2-C3- & 11 & 120. \\
O17 & 5 & 5 & C4 & 9 & 5 \\
\hline C4- & 1.3 & 1.4 & C2-C3- & 11 & 115. \\
C5 & 9 & 0 & O17 & 5 & 3 \\
\hline C4- & 1.0 & 1.0 & C4-C3- & 12 & 124. \\
H9 & 8 & 8 & O17 & 4 & 1 \\
\hline
\end{tabular}

\begin{tabular}{|c|c|c|c|c|c|}
\hline C5- & 1.3 & 1.4 & C3-C4- & 11 & 119. \\
C6 & 9 & 2 & C5 & 5 & 3 \\
\hline C5- & 1.0 & 1.0 & C3-C4- & 12 & 122. \\
H10 & 8 & 8 & H9 & 1 & 6 \\
\hline C6- & 1.4 & 1.4 & C5-C4- & 11 & 117. \\
C11 & 9 & 6 & H9 & 9 & 3 \\
\hline C11- & 1.5 & 1.5 & C4-C5- & 12 & 120. \\
C12 & 1 & 1 & C6 & 1 & 6 \\
\hline C11- & 1.2 & 1.2 & C4-C5- & 11 & 117. \\
O13 & 1 & 4 & H10 & 8 & 5 \\
\hline C12- & 1.0 & 1.0 & C6-C5- & 12 & 120. \\
H14 & 7 & 9 & H10 & 0 & 5 \\
\hline C12- & 1.0 & 1.0 & C1-C6- & 11 & 117. \\
H15 & 9 & 9 & C5 & 8 & 6 \\
\hline C12- & 1.0 & 1.0 & C1-C6- & 11 & 119. \\
H16 & 9 & 9 & C11 & 8 & 8 \\
\hline O17- & 1.4 & 1.3 & C5-C6- & 12 & 122. \\
C18 & 2 & 5 & C11 & 2 & 6 \\
\hline C18- & 1.0 & 1.0 & C6-C11- & 11 & 120. \\
H19 & 8 & 9 & C12 & 8 & 2 \\
\hline C18- & 1.0 & 1.0 & C6-C11- & 12 & 121. \\
H20 & 9 & 9 & O13 & 0 & 0 \\
\hline C18- & 1.0 & 1.0 & C12- & 12 & 118. \\
H21 & 9 & 9 & C11- & 0 & 8 \\
\hline
\end{tabular}

Taken from ref. [19]

Table. 2 .

Charges of 4-Methoxyacetophenone with B3LYP/6$311++\mathrm{G}(\mathrm{d}, \mathrm{p})$ basis set.

\begin{tabular}{|l|l|l|}
\hline \multirow{2}{*}{ Atoms } & \multicolumn{2}{|c|}{ B3LYP/6-311++G(d,p) } \\
\cline { 2 - 3 } & $\begin{array}{l}\text { Mullikan } \\
\text { Charge }\end{array}$ & $\begin{array}{l}\text { Natural } \\
\text { Charge }\end{array}$ \\
\hline $1 \mathrm{C}$ & 0.58319 & -0.1336 \\
\hline $2 \mathrm{C}$ & -0.60929 & -0.23825 \\
\hline $3 \mathrm{C}$ & -0.41809 & 0.34814 \\
\hline $4 \mathrm{C}$ & 0.022901 & -0.29677 \\
\hline $5 \mathrm{C}$ & -1.21423 & -0.1484 \\
\hline $6 \mathrm{C}$ & 1.362685 & -0.18275 \\
\hline $7 \mathrm{H}$ & 0.202525 & 0.23101 \\
\hline $8 \mathrm{H}$ & 0.194486 & 0.22067 \\
\hline $9 \mathrm{H}$ & 0.182218 & 0.21246 \\
\hline $10 \mathrm{H}$ & 0.143902 & 0.20645 \\
\hline $11 \mathrm{C}$ & -0.27543 & 0.55464 \\
\hline $12 \mathrm{C}$ & -0.46566 & -0.66787 \\
\hline $13 \mathrm{O}$ & -0.25818 & -0.56694 \\
\hline $14 \mathrm{H}$ & 0.207455 & 0.22837 \\
\hline $15 \mathrm{H}$ & 0.153484 & 0.2175 \\
\hline $16 \mathrm{H}$ & 0.153354 & 0.21746 \\
\hline $17 \mathrm{O}$ & -0.15116 & -0.53339 \\
\hline $18 \mathrm{C}$ & -0.30908 & -0.20621 \\
\hline & & \\
\hline
\end{tabular}


International Journal of Research in Advent Technology, Vol.7, No.4, April 2019 E-ISSN: 2321-9637

Available online at www.ijrat.orgS

\begin{tabular}{|l|l|l|}
\hline $19 \mathrm{H}$ & 0.180659 & 0.19453 \\
\hline $20 \mathrm{H}$ & 0.157094 & 0.17147 \\
\hline $21 \mathrm{H}$ & 0.157168 & 0.17149 \\
\hline
\end{tabular}

Table. 3 .

Calculated ${ }^{1} \mathrm{H}$ and ${ }^{13} \mathrm{C}$ NMR Chemical shifts (ppm) of 4-Methoxyacetophenone

\begin{tabular}{|c|c|c|c|}
\hline Atom & Gas & $\mathbf{C d C l}_{\mathbf{3}}$ & Exp. \\
\hline $1 \mathrm{C}$ & 135.59 & 134.42 & 130.57 \\
\hline $2 \mathrm{C}$ & 122.82 & 122.39 & 113.67 \\
\hline $3 \mathrm{C}$ & 170.06 & 170.95 & 163.48 \\
\hline $4 \mathrm{C}$ & 109.50 & 111.24 & 130.31 \\
\hline $5 \mathrm{C}$ & 135.82 & 134.42 & 130.31 \\
\hline $6 \mathrm{C}$ & 134.58 & 134.42 & 130.57 \\
\hline $11 \mathrm{C}$ & 198.50 & 202.1 & 196.75 \\
\hline $12 \mathrm{C}$ & 26.32 & 27.26 & 26.32 \\
\hline $18 \mathrm{C}$ & 55.20 & 55.74 & 55.45 \\
\hline $7 \mathrm{H}$ & 8.40 & 8.32 & 7.941 \\
\hline $8 \mathrm{H}$ & 7.14 & 7.17 & 6.935 \\
\hline $9 \mathrm{H}$ & 6.61 & 6.88 & 6.88 \\
\hline $10 \mathrm{H}$ & 7.86 & 8.08 & 7.922 \\
\hline $14 \mathrm{H}$ & 1.93 & 1.87 & 1.90 \\
\hline $15 \mathrm{H}$ & 2.55 & 2.75 & 2.40 \\
\hline $16 \mathrm{H}$ & 2.55 & 2.75 & 2.40 \\
\hline $19 \mathrm{H}$ & 4.05 & 4.14 & 4.00 \\
\hline $20 \mathrm{H}$ & 3.63 & 3.77 & 3.85 \\
\hline $21 \mathrm{H}$ & 3.63 & 3.77 & 3.60 \\
\hline
\end{tabular}

Table.4.

Vibrational Assignment

\begin{tabular}{|c|c|c|c|}
\hline \multicolumn{2}{|c|}{$\begin{array}{c}\text { Experimental } \\
\text { frequency } \\
\text { cm- }^{-}\end{array}$} & \multicolumn{2}{c|}{ Assignment } \\
\hline $\begin{array}{c}\text { FT- } \\
\text { IR }\end{array}$ & FT-Raman & Scaled & Band \\
\hline 3115 & & 3103 & $v \mathrm{CH}$ \\
\hline & 3084 & 3096 & $v \mathrm{CH}$ \\
\hline & & 3082 & $v \mathrm{CH}$ \\
\hline 3061 & 3061 & 3079 & $v \mathrm{CH}$ \\
\hline 3036 & & 3038 & $v \mathrm{CH}$ \\
\hline & 3003 & 3035 & $v \mathrm{CH}$ \\
\hline 2980 & & 2987 & $v \mathrm{CH}$ \\
\hline 2972 & & 2970 & $v \mathrm{CH}$ \\
\hline 2930 & & 2931 & $v \mathrm{CH}$ \\
\hline 2910 & & 2911 & $v \mathrm{CH}$ \\
\hline 1751 & & 1678 & $v \mathrm{CO}$ \\
\hline & 1664 & 1588 & $v \mathrm{CC}$ \\
\hline 1550 & & 1551 & $v \mathrm{CC}$ \\
\hline 1483 & & 1487 & $v \mathrm{CC}$ \\
\hline
\end{tabular}

\begin{tabular}{|c|c|c|c|}
\hline & 1463 & 1453 & $v \mathrm{CC}$ \\
\hline & 1439 & 1443 & $v C C$ \\
\hline & 1428 & 1430 & $v \mathrm{CC}$ \\
\hline & 1425 & 1426 & $v \mathrm{CC}$ \\
\hline & 1420 & 1422 & $v \mathrm{CC}$ \\
\hline & 1402 & 1401 & $\beta \mathrm{CH}$ \\
\hline 1348 & & 1338 & $\beta \mathrm{CH}$ \\
\hline 1315 & & 1307 & $\beta \mathrm{CH}$ \\
\hline 1278 & 1276 & 1284 & $\beta \mathrm{CH}$ \\
\hline 1250 & & 1244 & $\beta \mathrm{CH}$ \\
\hline 1235 & & 1234 & $\beta \mathrm{CH}$ \\
\hline \multirow[t]{4}{*}{1197} & & 1161 & $v \mathrm{CO}$ \\
\hline & 1150 & 1155 & vCO \\
\hline & 1100 & 1128 & $\beta \mathrm{CH}$ \\
\hline & 1080 & 1097 & $\beta \mathrm{CH}$ \\
\hline \multirow[t]{3}{*}{1064} & & 1054 & $\beta \mathrm{CH}$ \\
\hline & 1022 & 1017 & $\beta \mathrm{CH}$ \\
\hline & 1002 & 1007 & $\beta \mathrm{CO}$ \\
\hline 990 & & 988 & $\beta C C$ \\
\hline 970 & & 964 & $\beta \mathrm{CC}$ \\
\hline \multirow[t]{2}{*}{936} & & 923 & $\beta \mathrm{CC}$ \\
\hline & 918 & 915 & $\beta \mathrm{CC}$ \\
\hline \multirow[t]{3}{*}{833} & & 827 & $\beta \mathrm{CC}$ \\
\hline & 795 & 794 & $\beta C C$ \\
\hline & 750 & 788 & $\beta \mathrm{CC}$ \\
\hline 710 & & 715 & $\beta \mathrm{CC}$ \\
\hline 686 & 684 & 660 & $\gamma \mathrm{CH}$ \\
\hline 630 & & 623 & $\gamma \mathrm{CH}$ \\
\hline 592 & & 577 & $\gamma \mathrm{CH}$ \\
\hline \multirow[t]{3}{*}{578} & & 567 & $\beta \mathrm{CO}$ \\
\hline & 488 & 489 & $\beta \mathrm{CO}$ \\
\hline & 461 & 469 & $\gamma \mathrm{CH}$ \\
\hline 452 & & 443 & $\gamma \mathrm{CH}$ \\
\hline \multirow[t]{3}{*}{399} & & 406 & $\gamma \mathrm{CH}$ \\
\hline & 332 & 314 & $\gamma \mathrm{CH}$ \\
\hline & 292 & 285 & $\gamma \mathrm{CH}$ \\
\hline \multirow[t]{7}{*}{250} & & 258 & $\gamma \mathrm{CH}$ \\
\hline & 218 & 211 & $\gamma \mathrm{CH}$ \\
\hline & 150 & 161 & $\tau \mathrm{CCH}$ \\
\hline & 138 & 136 & $\tau \mathrm{CCH}$ \\
\hline & 126 & 121 & $\tau \mathrm{CCC}$ \\
\hline & & 68 & $\tau \mathrm{CCC}$ \\
\hline & & 55 & $\tau \mathrm{CCC}$ \\
\hline
\end{tabular}

$\nu$-stretching; $\beta$-in-plane bending; $\gamma$-out of plane bending; and $\tau$-torsion. 
International Journal of Research in Advent Technology, Vol.7, No.4, April 2019 E-ISSN: 2321-9637

Available online at www.ijrat.orgS

Table. 5 .

Second order perturbation theory of Fock matrix in NBO basis of 4-Methoxyacetophenone

\begin{tabular}{|c|c|c|c|c|c|c|}
\hline $\begin{array}{c}\text { Dono } \\
\mathbf{r}\end{array}$ & $\begin{array}{l}\mathbf{T} \\
\mathbf{y} \\
\mathbf{p} \\
\mathbf{e}\end{array}$ & $\begin{array}{c}\text { Oc } \\
\text { cup } \\
\text { anc } \\
\text { y }\end{array}$ & $\begin{array}{c}\text { Accep } \\
\text { tor }\end{array}$ & $\begin{array}{l}\mathbf{T} \\
\mathbf{y} \\
\mathbf{p} \\
\mathbf{e}\end{array}$ & $\begin{array}{l}\text { Occ } \\
\text { upa } \\
\text { ncy }\end{array}$ & $\begin{array}{l}\mathbf{E}( \\
2)\end{array}$ \\
\hline $\begin{array}{l}\text { C3- } \\
\text { C4 }\end{array}$ & $\square$ & $\begin{array}{r}1.9 \\
7\end{array}$ & $\begin{array}{l}\mathrm{C} 1- \\
\mathrm{C} 2\end{array}$ & $\begin{array}{l}\square \\
\square\end{array}$ & $\begin{array}{l}\square \square \\
\square \square \\
\quad \square\end{array}$ & $\begin{array}{r}34 . \\
9\end{array}$ \\
\hline O17 & $\mathrm{n}$ & $\begin{array}{r}1.8 \\
9\end{array}$ & $\begin{array}{l}\mathrm{C} 3- \\
\mathrm{C} 4\end{array}$ & $\begin{array}{l}\square \\
\square\end{array}$ & $\begin{array}{l}\square \square \\
\square \square \\
\square\end{array}$ & $\begin{array}{r}31 . \\
8\end{array}$ \\
\hline $\begin{array}{c}\text { C3 - } \\
\text { C4 }\end{array}$ & $\square$ & $\begin{array}{r}1.6 \\
4\end{array}$ & $\begin{array}{l}\mathrm{C} 5 \text { - } \\
\mathrm{C} 6\end{array}$ & $\begin{array}{l}\square \\
\square\end{array}$ & $\begin{array}{l}\square \square \\
\square \square \\
\square\end{array}$ & $\begin{array}{r}23 . \\
8\end{array}$ \\
\hline $\begin{array}{c}\mathrm{C} 1- \\
\mathrm{C} 2\end{array}$ & $\square$ & $\begin{array}{r}1.7 \\
0\end{array}$ & $\begin{array}{l}\mathrm{C} 3- \\
\mathrm{C} 4\end{array}$ & $\begin{array}{l}\square \\
\square\end{array}$ & $\begin{array}{l}\square \square \\
\square \square \\
\square\end{array}$ & $\begin{array}{r}23 . \\
4\end{array}$ \\
\hline $\begin{array}{c}\mathrm{C} 5- \\
\mathrm{C} 6\end{array}$ & $\square$ & $\begin{array}{r}1.6 \\
6\end{array}$ & $\begin{array}{l}\mathrm{C} 1- \\
\mathrm{C} 2\end{array}$ & $\begin{array}{l}\square \\
\square\end{array}$ & $\begin{array}{l}\quad \square \square \\
\square \square \\
\square\end{array}$ & $\begin{array}{r}20 . \\
5\end{array}$ \\
\hline O13 & $\mathrm{n}$ & $\begin{array}{r}1.8 \\
9\end{array}$ & $\begin{array}{l}\text { C11 - } \\
\text { C12 }\end{array}$ & $\begin{array}{l}\square \\
\square\end{array}$ & $\begin{array}{l}\square \square \\
\square \square \\
\square\end{array}$ & $\begin{array}{r}19 . \\
9\end{array}$ \\
\hline $\begin{array}{c}\mathrm{C} 5- \\
\mathrm{C} 6\end{array}$ & $\square$ & $\begin{array}{r}1.6 \\
6 \\
\end{array}$ & $\begin{array}{l}\text { C } 11- \\
\text { O13 }\end{array}$ & $\begin{array}{l}\square \\
\square\end{array}$ & $\begin{array}{l}\quad \square \square \\
\square \square \\
\square\end{array}$ & $\begin{array}{r}19 . \\
5\end{array}$ \\
\hline O13 & $\mathrm{n}$ & $\begin{array}{r}1.9 \\
7\end{array}$ & $\begin{array}{l}\text { C6 - } \\
\text { C11 }\end{array}$ & $\begin{array}{l}\square \\
\square\end{array}$ & $\begin{array}{l}\square \square \\
\square \square \\
\square\end{array}$ & $\begin{array}{r}18 . \\
4\end{array}$ \\
\hline
\end{tabular}

\section{Table: 6}

Theoretical electronic absorption spectra of 4Methoxyacetophenone (absorption wavelength $\lambda(\mathrm{nm})$, excitation energies $E(\mathrm{eV})$ and oscillator strengths (f) using TD-DFT/B3LYP/6-311++G(d,p) method.

\begin{tabular}{|c|c|c|c|c|}
\hline \multicolumn{2}{|c|}{$\lambda(\mathrm{nm})$} & \multirow{3}{*}{$\begin{array}{c}\mathbf{E}(\mathbf{e V} \\
)\end{array}$} & \multirow{3}{*}{ (f) } & \multirow{3}{*}{$\begin{array}{c}\text { Major } \\
\text { contribution }\end{array}$} \\
\hline $\mathbf{T}$ & $\mathbf{E}$ & & & \\
\hline \multicolumn{2}{|c|}{ Gas } & & & \\
\hline $\begin{array}{c}32 \\
3\end{array}$ & & $\begin{array}{c}3.83 \\
4\end{array}$ & $\begin{array}{l}0.000 \\
1\end{array}$ & $\begin{array}{l}\text { H-1->LUMO } \\
(97 \%)\end{array}$ \\
\hline $\begin{array}{c}26 \\
4\end{array}$ & & $\begin{array}{l}4.68 \\
8\end{array}$ & $\begin{array}{l}0.369 \\
2\end{array}$ & $\begin{array}{l}\text { HOMO->LUMO } \\
(95 \%)\end{array}$ \\
\hline $\begin{array}{c}25 \\
8\end{array}$ & & $\begin{array}{c}4.79 \\
7\end{array}$ & $\begin{array}{l}0.001 \\
9\end{array}$ & $\begin{array}{l}\text { H-2->LUMO } \\
(57 \%)\end{array}$ \\
\hline 23 & & 4.31 & 0.000 & H-1->L+1 (100\%) \\
\hline 1 & & 7 & 0 & \\
\hline $\begin{array}{c}22 \\
7\end{array}$ & & $\begin{array}{c}4.39 \\
5\end{array}$ & $\begin{array}{l}0.005 \\
9\end{array}$ & $\begin{array}{l}\text { HOMO->L+2 } \\
(99 \%)\end{array}$ \\
\hline $\begin{array}{c}22 \\
0\end{array}$ & & $\begin{array}{c}4.54 \\
4\end{array}$ & $\begin{array}{l}0.133 \\
8\end{array}$ & $\begin{array}{l}\text { H-2->LUMO } \\
(41 \%)\end{array}$ \\
\hline $\begin{array}{c}21 \\
0\end{array}$ & & $\begin{array}{c}4.75 \\
5\end{array}$ & $\begin{array}{l}0.004 \\
1\end{array}$ & $\begin{array}{l}\text { HOMO->L+3 } \\
(99 \%)\end{array}$ \\
\hline $\begin{array}{c}20 \\
9\end{array}$ & & $\begin{array}{c}4.77 \\
2\end{array}$ & $\begin{array}{l}0.020 \\
3\end{array}$ & H-1->L+2 (80\%) \\
\hline $\begin{array}{c}20 \\
2\end{array}$ & & $\begin{array}{c}4.93 \\
6\end{array}$ & $\begin{array}{l}0.000 \\
0\end{array}$ & $\begin{array}{l}\text { HOMO->L+4 } \\
(94 \%)\end{array}$ \\
\hline $\begin{array}{c}19 \\
7\end{array}$ & & $\begin{array}{c}5.05 \\
2\end{array}$ & $\begin{array}{l}0.002 \\
4\end{array}$ & H-2->L+2 (94\%) \\
\hline
\end{tabular}

\begin{tabular}{|c|c|c|c|c|}
\hline \multicolumn{2}{|c|}{ Ethanol } & & & \\
\hline $\begin{array}{c}31 \\
1\end{array}$ & & $\begin{array}{c}3.98 \\
6\end{array}$ & $\begin{array}{c}0.000 \\
1\end{array}$ & $\begin{array}{l}\text { H-1->LUMO } \\
(97 \%)\end{array}$ \\
\hline 27 & 27 & 4.51 & 0.467 & HOMO->LUMO \\
\hline 4 & 1 & 4 & 2 & $(97 \%)$ \\
\hline 26 & & 4.74 & 0.001 & H-2->LUMO \\
\hline 1 & & 7 & 9 & $(64 \%)$ \\
\hline 22 & & 4.44 & 0.161 & H-2->LUMO \\
\hline 5 & & 4 & 6 & $(34 \%)$ \\
\hline 22 & & 4.53 & 0.000 & H-1->L+1 (100\%) \\
\hline 0 & & 8 & 0 & \\
\hline 21 & & 4.61 & 0.005 & HOMO- \\
\hline 6 & & 0 & 8 & $>\mathrm{L}+2(97 \%)$ \\
\hline 20 & & 4.94 & 0.006 & HOMO->L+3 \\
\hline 2 & & 1 & 5 & $(96 \%)$ \\
\hline 19 & & 5.04 & 0.000 & HOMO- \\
\hline 8 & & 2 & 3 & $>\mathrm{L}+4(96 \%)$ \\
\hline 19 & & 5.08 & 0.077 & H-1->L+2 (78\%) \\
\hline 6 & & 8 & 7 & \\
\hline 19 & & 5.16 & 0.317 & H-2->L+1 (70\%) \\
\hline 3 & & 6 & & \\
\hline
\end{tabular}

Table. 7.

Homo-Lumo of 4-Methoxyacetophenone.

\begin{tabular}{|l|c|}
\hline Parameters & ethanol \\
\hline $\mathrm{E}_{\mathrm{HOMO}}(\mathrm{eV})$ & 0.24468 \\
\hline $\mathrm{E}_{\mathrm{LUMO}}(\mathrm{eV})$ & 0.06574 \\
\hline$\Delta \mathrm{E}_{\mathrm{HOMO}-\mathrm{LUMO} \text { gap }}(\mathrm{eV})$ & 0.17894 \\
\hline Elecronegativity $(\chi)(\mathrm{eV})$ & -0.15521 \\
\hline Global hardness $(\eta)(\mathrm{eV})$ & -0.08947 \\
\hline Global softness $(\mathrm{S})(\mathrm{eV})$ & -11.1769 \\
\hline Electrophilicity index $(\omega)(\mathrm{eV})$ & -0.13462 \\
\hline Dipole Moment $(\mu)($ debye $)$ & 4.9769 \\
\hline
\end{tabular}

Table 8:

Thermodynamic properties at different temperatures of 4Methoxyacetophenone

\begin{tabular}{|c|c|c|c|}
\hline $\begin{array}{c}\mathbf{T} \\
(\mathbf{K})\end{array}$ & $\begin{array}{c}\mathrm{C}_{\mathrm{m}}{ }^{\circ} \\
(\mathrm{cal} \\
\mathrm{mol}^{-1} \\
\left.\mathrm{~K}^{-1}\right)\end{array}$ & $\begin{array}{c}\mathbf{S}_{\mathrm{m}}{ }^{\circ} \\
(\mathrm{cal} \\
\mathbf{m o l}^{-1} \\
\left.\mathbf{K}^{-1}\right)\end{array}$ & $\begin{array}{c}\Delta \mathbf{H}_{\mathrm{m}}{ }^{\circ} \\
(\mathrm{cal} \\
\mathrm{mol}^{-1} \\
\left.\mathbf{K}^{-1}\right)\end{array}$ \\
\hline 100 & 17.05 & 74.33 & 107.3 \\
\hline 200 & 27.85 & 90.83 & 109.5 \\
\hline 300 & 39.27 & 105.0 & 112.9 \\
\hline
\end{tabular}

Table 9.

Molecular docking analysis of 4-Methoxyacetophenone

\begin{tabular}{|c|c|c|c|}
\hline $\begin{array}{c}\text { Protein } \\
\text { (PDB } \\
\text { ID) }\end{array}$ & $\begin{array}{c}\text { No. of } \\
\text { hydrogen } \\
\text { bonds }\end{array}$ & $\begin{array}{c}\text { Bonded } \\
\text { Residues }\end{array}$ & $\begin{array}{c}\text { Bond } \\
\text { Distance } \\
\AA\end{array}$ \\
\hline 5 VCX & 2 & CYS 190 & 2.0 \\
\hline & & ASP 251 & 2.3 \\
\hline
\end{tabular}


International Journal of Research in Advent Technology, Vol.7, No.4, April 2019 E-ISSN: 2321-9637

Available online at www.ijrat.orgS

\section{Acknowledgments}

We remain grateful to Kanchi Mamunivar Center for Post Graduates studies, Lawspet, Puducherry for providing the Quantum Computational Research Lab for this study.

\section{REFERENCES}

[1] R.N. Griffin, R.N; (1968): Photochem. Photobiol. 7 pp. 159.

[2] Lindqvist, L.; (1972) Phys. Chem. Pp.821.

[3] Boido, V.; Di Maio-Aapello, B.; (1974) Boll. Chim. Farm (113) pp.344.

[4] www. chemicalland 21.com

[5] Arjunan, V.; Devi, L.; Subbalakshmi, R.; Rani, T.; Mohan, S; (2014) SpectrochimicaActa Part A: Molecular and Biomolecular Spectroscopy 130 pp.164-177.

[6] Sittig, M.; (1985) Handbook of Toxic and Hazardous Chemicals and Carcinogens, second ed., Noyes Publications, Park Ridge, NJ.

[7] Stewart, R.; Yates, K.; (1958) J. Am. Chem. Soc. 80 pp. 6355.

[8] Source: Human Metabolome Database (HMDB)Record Name: 4'-Methoxyacetophenone URL: http://www.hmdb.ca/metabolites/HMDB00325 70, April 15, 2019.

[9] Forsen, S.; Akermark, B.; Alm, T.; (1964) Acta Chem. Scand. 18 pp. 2313-2328.

[10] Ahmad, J.; Anderson, A.; Rochester, C.H.; Dines, T.J.; (1998) J. Mol. Catal. Chem. (135A) pp. 6373.

[11] Frisch, M.J.; Trucks, G.W.; Schlegel, H.B.; Scuseria, G.E.; Robb, M.A.; Cheeseman, J.R.; Scalmani, G.; Barone, V.; Mennucci, B.; Petersson, G.A., Nakatsuji, H., Caricato, M., Li, X., Hratchian, H.P., Izmaylov, A.F., Bloino, J., Zheng, G., Sonnenberg, J.L., Hada, M., Ehara, M., Toyota, K., Fukuda, R., Hasegawa, J., Ishida, M., Nakajima, T., Honda, Y., Kitao, O., Nakai, H., Vreven, T., Montgomery Jr., J.A., Peralta, J.E., Ogliaro, F., Bearpark, M., Heyd, J.J., Brothers, E., Kudin, K.N., Staroverov, V.N., Kobayashi, R., Normand, J., Raghavachari, K., Rendell, A., Burant, J.C., Iyengar, S.S., Tomasi, J., Cossi, M., Rega, N., Millam, J.M., Klene, M., Knox, J.E., Cross, J.B., Bakken, V., Adamo, C., Jaramillo, J., Gomperts, R., Stratmann, R.E., Yazyev, O., Austin, A.J., Cammi, R., Pomelli, C., Ochterski, J.W., Martin, R.L., Morokuma, K., Zakrzewski, V.G., Voth, G.A., Salvador, P., Dannenberg, J.J., Dapprich, S., Daniels, A.D., Farkas, O., Foresman, J.B., Ortiz, J.V., Cioslowski, J. and Fox, D.J. (2009) Gaussian 09, Revision A.02. Gaussian, Inc., Wallingford.

[12] Roy, D.D., Todd, A.K. and John, M.M. (2009) Gauss View 5.0.8. Gaussian, Inc., Wallingford.

[13] Jamroz, M.H.; (2004) Vibrational energy distribution analysis, VEDA 4.

[14] O'boyle, N.M.; Tendrholt, A.L.; Langer, K.M.; (2008) J. Comput. chem.29 (5) pp. 839-845.
[15] Bakkiyaraj, D.; Periyandy, S.; Xavier, S.; (2016) J. Mol. Struct. Doi: http//doi.org/10.1016/j.molstruc.2016.04.096.

[16] Udayakumar, V.; Periandy, S.; Karabacak. M.; and Ramalingam. S.; (2011) Journal of Spectrochim(iAalActa Part A 83 pp. 575-586.

[17] Jain, F.F.; Zhao, P.S.; Bai, Z.S.; Zhang, L.; (2005) Struct.Chem.161 pp. 635-639.

[18] Reed, A.E.; Weinhold, F.; (1985) J.Chem.Phys.83 pp. 735-746.

[19] Arjunan, V.; Devi, L.; Subbalakshmi, R.; Rani, T.; Mohan, S.; (2014) SpectrochimicaActa Part A: Molecular and Biomolecular Spectroscopy 130 pp. 164-177.

[20] Karunakaran, V.; Balachandran, V.; (2014) SpectrochimicaActaPart A: Molecular and Biomolecular spectroscopy 128 pp.1-14.

[21] Sivaranjani, T.; Xavier, S.; Periandy, S.; (2015) J. Mol. Struct. 1083 pp. 39-47.

[22] Ahmad, S; Mathew, S.; Varma, P.K., (1992) Indian journal of pure and applied physics, $30 \mathrm{pp}$. 764-770.

[23] Stetter, H.; Rauscher. E (1960) Chem.Ber.93 pp. 2054.

[24] Ryan, A.G.; Welling., P.G.; Wright, S.E.; (1969) Food Cosmet.Toxicol. 7 (4) pp. 287.

[25] Muthu, S.; Isacpaulraj, E.; (2012) soild state science, 14 pp.476.

[26] Bellamy, L.L.; (1975) The Infrared Spectra of Complex Molecules, third ed., Wiley, New York.

[27] Sing, V.B.; (2007) Indian J.Pure Appl. Phys. 45 pp. 721-725.

[28] Varsanyi, G.; (1969) Vibrational Spectra of Benzene Derivatives, Academic Press, New York.

[29] Weinhold, F. and Landis, C.R. (2001) Natural Bond Orbitals and Extensions of Localized

Bonding Concepts. Chemistry Education Research and Practice, 2, pp.91-104.

[30] Pulay, P.; Fogarasi, G.; Ponger, G.; Boggs, J.E.; Vargha, A.; (1983) J. 1 Am. Chem. Soc. 105 pp. 7073-7078.

[31] Fogarasi, G.; Zhou, X.; Taylor, P.W.; Pulay, P.; (1992) J. Am. Chem. Soc. 114 pp. 819148201.

[32] [33] Dal, J.; Sinha, N.; Yadav, H.; Kumar, B.; (2015) RSC, Adv. 5 pp.57735-57748.

[33] Vitnik, V.D., Vitnik, Z.J., Banjac, N.R., Valentic, N.V., Uscumlic, G.S. and Juranic, I.O. (2014) Quantum Mechanical and Spectroscopic (FT-IR, 13C, $1 \mathrm{H}$ NMR and UV) Investigations of Potent Antiepileptic Drug 1-(4-Chloro-Phenyl)- 3Phenyl-Succinimide. SpectrochimicaActa Part A: Molecular and Biomolecular Spectroscopy, 117, pp.42-53.

http://dx.doi.org/10.1016/j.saa.2013.07.099.

[34] Govindarasu, K.; Kavitha, E.; (2014) SpectrochimaActa Part A: Molecular and Biomolecular spectroscopy 122 pp. 130-141. 
[35] Ott, J.B.; Boerio-Goates, J.; (2000) Chemical Therodynaics: Advanced Applications, Calculations from statistical thermodynamics, Academic press.

[36] Lagunin, A.; Stepanchikova, A; Filimonov, D; Poroikov, v.; (2000) Pass: Prediction of activity spectra for biologically active substances, Bioinformatics, 16 pp. 747-748.

[37] Lia M. Godinho \& Isabelde Sa-Nogueira (2011) Journal of FEBS J. 278(14), pp. 25112524. 